\title{
MARCIN LEŹNICKI
}

Zakład Filozofii Moralnej i Bioetyki, UMK Toruń

\section{Wartość życia u podstaw islamskiej (bio)etyki ${ }^{1}$}

Słowa kluczowe: islam, Koran, Allach, sunnici, szyici, szaria/t, wartość życia, świętość życia, człowiek, wspólnota ludzka, dusza, grzech, aksjologia, bioetyka islamska Key words: Islam, Quran, Allah, Sunnis, Shi'a, sharia law, value of life, sanctity of life, man, human community, soul, sin, axiology, Islamic bioethics

\section{SUMMARY The value of life at the core of Islamic (bio)ethics}

The aim of this article is to present the position of Islamic ethics and bioethics on the issue of the value of life. To better illustrate this topic the article is divided into two parts. In the first, the authors provide an overview of ethics, and relate it Islamic bioethics, including its sources and inspirations, while in the second, the authors examine the value of life as depicted from the perspective of Quranic ethics and Islamic

1 Zastosowany w tytule i podtytułach poszczególnych rozdziałów tekstu, jak również przewijający się w ramach całego artykułu zapis pojęcia bioetyka w nawiasie półokrągłym, jako (bio)etyka służy dodatkowemu wskazaniu czytelnikowi, że islamska etyka ogólna w wielu miejscach przenika się, czy wręcz pokrywa, tak problemowo, jak i tematycznie z jej gałęzią szczegółową, tj. islamską bioetyką (koraniczną). Rzeczona notacja służy, zatem ukazaniu wzajemnego powinowactwa etyki i bioetyki, dla której ta pierwsza stanowi istotny punkt odniesienia. Wobec powyższego zauważyć można możliwość zniesienia nawiasów w pojęciu (bio)etyka, w miejsce którego wprowadzić można nie umniejszający merytorycznej charakterystyce tekstu, zapis etyka i bioetyka, sam zaś tytuł można natomiast alternatywnie odczytać, jako Wartość życia u podstaw islamskiej etyki i bioetyki. 
bioethics of both the Shia and the Sunnis. Although the text has a propedeutic character it is important because it adds another theologico-philosophical layer to the complex bioethical discussion that lies at the heart of the current dispute about the value of human life.

\section{Podstawy (bio)etyki islamskiej}

Pytając o rudymenty etyki i ufundowanej na niej bioetyki islamskiej, jak też podjęty w ich ramach namysł nad wartościowaniem życia ludzkiego powinniśmy na wstępie zastanowić się nad fundamentami islamu, nad źródłowymi inspiracjami wiary muzułmańskiej, z których czerpie ona pouczenia, normy postępowania, jak też wartości, do których się odwołuje. Dopiero, w tak zarysowanej perspektywie próbować można lokalizować temat, który nas w poniższej pracy interesuje, tj. wskazać, jaki jest stosunek islamskiej bioetyki do życia, jak też jego ewentualnej wartości. Każda bowiem bioetyka, czy to świecka, czy laicka pytając o zakres moralnie dopuszczalnych (bio)ingerencji w organizm, tak ludzki, jak i pozaludzki pytać będzie na początku, o wartość życia istoty poddanej rzeczonym manipulacjom. To zaś, czy będą one związane z inicjacją życia (by przywołać problemat in vitro, czy klonowania reprodukcyjnego), jego korekcją (by odwołać się do technologii transplantacyjnych), bądź też jego zakończeniem (by posłużyć się ilustracją eutanazji) pozostaje kwestią zasadniczo wtórną, którą trudno jest rozważać w ujęciu pozaaksjologicznym, tj. bez prekluzyjnego zdefiniowania, czym jest wartość życia?

Islam, jako jedna z najmłodszych religii monoteistycznych świata (powstała w I połowie VII wieku) w momencie powstania ufundowana została na dwojakiej podstawie filozoficzno-teologicznej. Pierwszą jest dla islamu, jako religii księgi - Koran, w którym zawarte zostało posłanie, które Allach, poprzez archanioła Gabriela objawił prorokowi Mahometowi. Dlatego też, bardzo często etykę oraz filozofię islamską nazywa się koranicznymi, jak w przypadku koranicznej (bio)etyki islamskiej, która bezpośrednio odwołuje się do Świętej Księgi Islamu. 
Drugim źródłem, jak konstatuje chociażby Azim Nanji będzie [e]gzemplifikacja tego posłania w postępowaniu Proroka, jego nauczaniu i przykładzie, które wspólnie określane sa jako sunna [ukazująca] ${ }^{2}$ historyczne ucieleśnienie moca boska inspirowanego i kierowanego ludzkiego życia proroka Muhammada [...] (Nanji 1988: 141).

W nakreślonej wyżej perspektywie Koran oraz życie Mahometa stały się wzorem (matrycą) postępowania dla muzułmanów, a tym samym stanowić zaczęły fundament, na którym zbudowano, $\mathrm{z}$ jednej strony aksjologiczno-etyczny system słusznego postępowania, z drugiej zaś islamski system prawno-legislacyjny (tj. szariat) ${ }^{3}$, w wymiarze tak formalnym, jak też pozaformalnym. Ten ostatni wywodzi się zresztą i bazuje na uznawanych w islamie normach i wartościach porządku moralnego, chociaż kładzie się w nim nacisk na precyzyjne określenie zasad prawnego postępowania wyznawców islamu na płaszczyźnie nakazowo-zakazowej (Por. Hallaq 2009). O ile zatem, islamska etyka i prawo przenikają się oraz uzupełniają a w ich wzajemnej korelacji dostrzec można harmonię, jako że etyka stanowi podbudowę dla stanowionego prawa, o tyle zadania stawiane przed etyką i prawem są często odmienne. Rozważania etyków islamskich zwrócone będą bowiem zasadniczo w stronę określenia standardów postępowania moralnego, których przestrzeganie ma się przyczynić do minimalizacji cierpienia w świecie, pomnażania szczęścia wiernych w Bogu, tak na tym świecie, jak i poza nim, dążenia do doskonałości leżącej w naturze człowieka i bliskiej Allachowi, czy szerzej rozwoju duchowego wyznawców islamu. Etyka islamska ma jednakże charakter przede wszystkim recepturalny, wskazujący, czy też proponujący, zamiast nakazowo-zakazowego, obowiązkowego, czy kategorycznego, jak w przypadku koranicznego prawa islamskiego. Ono tymczasem, wtórnie interesuje się rozwojem duchowym człowieka, jego szczęściem, czy też przestrzeganiem zasad porządku moralnego, których złamanie nie musi implikować sankcji prawnych

Wszystkie przypisy w nawiasach kwadratowych są autorskie.

W pracy poniższej terminy szariat i szaria stosowane są zamiennie. Zastosowany zabieg jest dopuszczalny, gdyż rzeczone pojęcia mają charakter tożsamy. 
a włącznie potępienie etyczne. $Z$ tego też jasno wynika, że złamanie określonych norm i zasad postępowania, może spotkać się z trojakiego rodzaju oceną takiego postępowania, tj. sankcją moralną, prawną, jak też prawno-moralną, chociaż zakres obowiązywania sankcji może być i zazwyczaj jest różny, tak jak i różne mogą być działania podlegające rzeczonej ocenie. Warto przy tym nadmienić, że wspomniane powyżej trzy rodzaje sankcji obecne są również w bioetyce islamskiej, w ramach której wyszczególnia się czyny zabronione w sensie etyczno-moralnym, sprzeczne z prawem, jak i takie, które pociągają za sobą określone konsekwencje moralno-prawne, czego dobrą egzemplifikacją może być niełatwy kazus aborcji, czy też in vitro.

Do powyższego dodać również warto, że szaria, tj. skodyfikowane prawo islamskie została podzielona, z uwagi na rodzaj czynów, które stały się ludzkim udziałem. Przykładowo George Makdisi podejmując się kategoryzacji oceny ludzkich działań zauważa, że w oparciu o Koran i Sunnę, jako filary islamu, stanowiące trzon etyczno-moralny opracowano kodeks norm, wartości, nakazów i zakazów objawionych wiernym przez Boga tj. szarię, w ramach której [P]rzyjęto pięć kategorii oceniania wszelkich działań, z czego [kluczowe pozostają] 1.Czyny obowiązkowe [jak choćby] udzielanie zakat [oraz] 5.Działania kategorycznie zakazane, takie jak morderstwo, czy też [brak szacunku dla drugiego człowieka, czy wreszcie] bluźnierstwo [...] (Nanji 1988: 148). Wszystkie ze wspomnianych powyżej działań, czy to nakazowych, czy też zakazowych mają na względzie w punkcie wyjścia dobrostan życia zarówno człowieka indywidualnego, jak też zbiorowości ${ }^{4}$ (wspólnoty muzułmańskiej - ummy), w której ten żyje, część jej nieodrodną stanowiąc.

Człowiek zaś, co należy wyraźnie podkreślić, działać powinien w zgodzie z pierwotnym porządkiem moralnym przedłożonym (objawionym) wiernym przez Boga w Koranie i Sunnie, kierując się przy tym mocą swego rozumu (al- 'agl), który umożliwia ludziom rozpoznawać słuszne działania i odstępować od wszelkich działań niegodziwych. Stąd też przyjmuje się i podkreśla, że islam opiera się na trzech

$4 \quad$ Na temat dobrostanu życia w relacji jednostka-wspólnota (Patrz: Jaroszewski 1970) 
filarach, tj. Koranie, sunnie oraz rozumie człowieka, z których każdy jest równie ważny, gdyż każdy pochodzi bezpośrednio od Boga - Allacha. $Z$ tego też wynika, że również islamska bioetyka koraniczna oparta będzie na Koranie, sunnie i rozumie (człowieka), nad którymi pieczę sprawuje Allach.

W surze XXV (Al-Furkan) Koranu czytamy:

Błogosławiony niech będzie

Ten, który zesłał rozróżnienie Swemu słudze, aby był ostrzegającym dla światów !

[i dalej]

... twój Pan wystarczy jako przewodnik po drodze prostej i jako wspomożyciel!

(Koran XXV: 1, 31)

Koran wyraźnie wskazuje tym samym na rolę Boga - przewodnika człowieka, tego który upomina, wskazuje, przypomina właściwe ścieżki postępowania, albowiem istota ludzka jest słaba, działa pochopnie, niecierpliwie, małodusznie, zapominając o dopełnianiu obowiązków względem Allacha oraz bliźnich. Stąd i potrzeba bożego wskazania, przewodnictwa i opieki, którą Bóg zsyła człowiekowi w chwili stworzenia (Koran XXIII: 14) a ściślej animacji ${ }^{5}$ istoty ludzkiej, kiedy to Allach tchnął w człowieka duszę (nafs) bezpośrednio odpowiedzialną przed Stwórcą za wszelkie ludzkie działania. Powyższe wiązać należy $\mathrm{z}$ utożsamieniem posiadania duszy z przydaną człowiekowi wolnością

$5 \quad$ W islamie przyjmuje się zarówno koncepcję animacji wczesnej, bezpośredniej, czy też równoczesnej, jak też wtórnej, lub opóźnionej, co uzależnione jest m. in. od rozpatrywanej tradycji islamskiej, tj. szyickiej, bądź też sunnickiej. W myśl dominującego stanowiska pełnia ludzkiego życia, jako życia duchowego rozpoczyna się po około 120 dniach od momentu zapłodnienia, kiedy to istota ludzka zostaje animowana. Mniejszość zakłada, że istota ludzka zostaje uduchowiona w 40 dniu od chwili zapłodnienia. Za przyjęciem stanowiska, w myśl którego człowiek zostaje animowany bezpośrednio po poczęciu, tj. w chwili zlania się plemnika z komórką jajową optuje niewielki odsetek muzułmanów. Różnice interpretacyjne nie wpływają jednak na sposób postrzegania boskiej opieki, którą Allach nad nami roztacza, od początku naszego biologicznego istnienia. (por. Majlesi 1983: 76) 
warunkującą podejmowanie tak złych, jak i dobrych uczynków. W takim też kontekście duszę powinniśmy traktować, jako najwyższy dar od Boga dla człowieka, „ogniwo korespondencji” z Absolutem, przejaw naszej wyjątkowości, której Bóg chciał dla nas samych, a także wyzwanie do odpowiedzialnego działania, przed którym zostaliśmy postawieni. Przykładowo Honorata Cyrzan konstatuje, że jeżeli dusza [...] oznacza to, co określamy jako duchowość człowieka, czyli ośrodek świadomości, woli i uczuć [...] (Cyrzan 1997: 153), jak również rozumności, to wskazaną wolność wiązać należy z wyborem, którego dokonuje człowiek, wyborem prawdy od fałszu, dobra od zła, tego co rzeczywiste od tego, co rzeczywistym nie jest i wielu innych. Niemniej jednak, człowiek w swoich wyborach błądzi, czego najbardziej znamienitym przykładem był los pierwszego człowieka - Adama, dusza zaś spowinowacona blisko z rozumem, winna nam służyć niczym „kompas słusznego postępowania”.

Co jednak, gdy zbłądzimy z właściwej ścieżki postępowania, bądź nie będziemy wiedzieli, jaką ścieżkę wybrać? W pierwszym przypadku filozofia oraz ufundowana na niej (bio)etyka islamska ocenę czynów ludzkich uzależnia od intencji towarzyszących działającemu. Między innymi Al-Ghazali pisze, [U]czynki sq zwiazane $z$ intencjami $i$ dla każdego na tyle, na ile miał intencje [...] (Al-Ghazali 1994: 42; Cyrzan 1997: 158). Oznacza to, że filozofia i (bio)etyka islamska mają charakter intencjonalny, gdzie ocenę uczynku (postępowania) oraz ewentualne nałożenie sankcji uzależnia się od zamysłu, z jakim przystępujemy do działania. W drugim przypadku, tj. w sytuacji braku umiejętności wyboru właściwej ścieżki postępowania, islam po pierwsze odwoływać sie będzie do "głosu rozumu” wspólnego ludziom, gdyż otrzymanego od Stwórcy, czy „podszeptu duszy”, jak również, praktycznej wykładni (etyczno)-religijnej, którą szyitom przedstawiają wprawni w prawie i moralności ajatollahowie, sunnici natomiast szukać będą analogii (giyas) pomiędzy aktualnie podejmowanymi działaniami a zbieżnymi z nimi działaniami, opisanymi uprzednio w Koranie i Sunnie, jako „weryfikatorach” słusznego postępowania. Warto przy tym dodać, że 
o ile w islamie szyickim i opartej na nim koranicznej (bio)etyce islamskiej decydujący będzie ostatecznie przewodni głos ajatollahów, o tyle w przypadku islamu sunnickiego i ufundowanej na nim (bio)etyce zauważyć można wzmożone zainteresowanie dyskursywnym konsensusem (ijmaa) zamiast monopolu światopoglądowo-wyznaniowego, jak też prawnego ajatollahów.

$\mathrm{Z}$ tego, co zostało powyżej wynika zatem, iż (bio)etyka islamska ufundowana została na Koranie i sunnie (Por. Gatrad et al. 2001, Shomali 2008, Padela 2007), które to stanowią podbudowę dla stanowionego prawa, w tym bioprawa i bioetyki, w tym etyki medycznej oraz aksjomedycyny. Człowiek zaś, w tym rozstrzygający praktyczne zagadnienia dylematyczne $\mathrm{z}$ zakresu biomedycyny bioetyk mocą swojego rozumu utożsamionego, czy też spowinowaconego $\mathrm{z}$ duszą powinien podejmować słuszne (właściwe) działania, w sensie, tak moralnym, jak i prawnym. Na straży godziwego postępowania, w tym działania zajmującego uwagę (bio)etyków stoją ponadto ważni dla islamu szyickiego ajatollahowie, jak również świadectwo Koranu i Sunny pojmowane w duchu analogii oraz zakładanego konsensusu, do których wzywa islam sunnicki. Islamska (bio)etyka sunnicko-szyicka nawołuje ponadto, do realizacji tzw. trzech praktyk, tj. należności i zobowiązania (w tym ochrony zdrowia i życia człowieka, w tym jego leczenia), przestrzegania prawa (wobec Boga, wspólnoty i jednostki ludzkiej) oraz cnotliwości (Ihsan), w tym bogobojności (Daar, Khitamy 2001: 60-3). Dodać przy tym należy, że wskazane powyżej praktyki mają charakter aksjo-teologiczny, $\mathrm{tj}$. ich realizacja możliwa jest, $\mathrm{z}$ uwagi na posiadaną przez nas wolność, która wraz z inteligencją oraz mową stanowią trzy elementy boskie w człowieku nadające nam szczególny status i wartość naszemu życiu, które to, jak podkreślają myślicieli islamscy powinniśmy szanować, chronić prawnie, jak też objąć „parasolem” moralności i wiary. Co więcej, o rzeczonych powyżej trzech praktykach mówi się w islamie, jako boskich, gdyż przez Boga - Allacha w człowieku zaszczepionych.

Do wyjaśnienia pozostało natomiast pytanie, dlaczego życie ludzkie ma wartość? 


\section{Lokacja wartości życia w koranicznej etyce i bioetyce islamskiej}

Nawiązując do tego, co zostało już powiedziane we wcześniejszej części tekstu zauważyć należy, że w tradycji islamskiej życie (ludzkie ${ }^{6}$ ) postrzegane było i jest, jako największy dar, jaki człowiek otrzymał od Boga, zaś sam akt ofiarowania życia traktuje islam, jako naoczny akt bożego błogosławieństwa i uświęcenia człowieka ${ }^{7}$ - poprzez życie - które od momentu bożej inicjacji nie jest już życiem li tylko biologicznym, lecz staje się ono życiem duchowym a co za tym idzie świętym, niezbywalnym i nienaruszalnym ${ }^{8}$. Wartość ludzkiego życia ma tym samym charakter stały, bądź niezmienny, albowiem nie wzrasta ona stopniowo ani nie maleje w czasie, w ujęciu „sinusoidalnym”, lecz utrzymuje się na stałym aksjo-poziomie - od chwili (naturalnego ${ }^{9}$ ) poczęcia, aż po kres człowieczej egzystencji ${ }^{10}$. Co więcej, jak zgodnie dodają teolodzy i aksjo-ontolodzy islamscy, niezmienna wartości życia rozpatrywana może a nawet powinna być zarówno w pespektywie holistycznej, kiedy to mówimy o życiu, jako czasowym kontinuum, bądź też trwale postępującym procesie, czy przebiegu, jak również w ujęciu „punktowym”, gdy to każdej chwili życia, danemu jego wyimkowi, bądź fragmento-

$6 \quad$ Przedmiotem zainteresowania niniejszej pracy jest z założenia życie ludzkie. Nie oznacza to jednak, braku opracowań poświęconych wartościowaniu życia pozaludzkiego. Takie studia również możemy odnaleźć, chociaż nie zostaną ona poddane analizie $\mathrm{w}$ ramach poniższego tekstu.

7 Uświęcenie istoty ludzkiej darem życia, islam dzieli m.in. z chrześcijaństwem.

8 Dlatego też tradycja islamska posługuje się kategorią świętości życia w sensie jego nienaruszalności, nie zaś kategorią jakości życia, która nie jest stała. Patrz: Abdur-Rashid et al. 2013, Brockopp 2003, Atighetchi 1994, El-Abbadi 1990.

9 Islam zalecać będzie naturalną prokreację, sztuczna zaś reprodukcja, jako nienaturalna powinna być zdaniem znacznej części myślicieli islamskich wyeliminowana, bądź też ograniczona w stosowaniu (patrz: Larijani et al. 2004, Atighetchi 2000).

10 Myśliciele islamscy określając wobec powyższego wartość życia wczesnego człowieka odwoływać się będą do biologiczno-genetycznego kryterium funkcjonalności człowieka od początku, zwanego również kryterium od zapłodnienia, genetycznym, ciągłości szlaku rozwojowego istoty ludzkiej, czy też kryterium genealogicznym. Do polskiej literatury branżowej z obszaru bioetyki, powyższe kryterium wprowadza m.in. Tadeusz Biesaga (Patrz: Biesaga 2007). 
wi życia, z uwagi na jego skończoność, przemijalność i ulotność, jak również nieodwracalność a co za tym idzie niepowtarzalność należy przypisać jednaką wartość. W związku z powyższym, wszelkie ludzkie życie, niezależnie od jego jakości winniśmy chronić i jednako wartościować, z uwagi na obdarzonego tym życiem człowieka, jak też Darczyńcę Życia - Boga.

Przydanie wartości życiu człowieka następuje, tym samym na poziomie (antropologiczno)-teologicznym, tj. w kontekście Bożego ofiarowania (dawstwa życia) oraz kreacji człowieka na obraz oraz podobieństwo Boże, kiedy to Stwórca - Allach [...] zawart [w nas] odbicie swojej istoty, atrybutów i czynów [...] (Piwiński 1983: 34; Cyrzan 1997: 154); Stanowiący ukoronowanie dzieła stworzenia człowiek staje się odtąd następcą (chalifa) Stwórcy na ziemi (Nasr 1988: 20; Cyrzan 1997: 154). Sukcesorem wyjątkowym, gdyż w hierarchii bytów już pierwszy człowiek - Adam staje powyżej aniołów, które mają oddawać mu cześć i szacunek poprzez (symboliczny) pokłon, o czym zaświadcza Koran w słowach:

Oto powiedział mój Pan do aniołów:

„Ja stwarzam człowieka z gliny.

Kiedy go ukształtuję harmonijnie

i tchnę w niego Mojego Ducha,

to padnijcie oddając mu pokłony!”

Wtedy pokłonili się aniołowie wszyscy razem,

z wyjątkiem Iblisa;

on wbił się w pychę

i znalazł się wśród niewiernych

$[\ldots]$

(Koran XXXVIII: 71-75)

Napomknąć jednocześnie należy, iż każdy człowiek poczynając od Adama błądzi, aby więc nasze życie miało wartość winniśmy dążyć do podporządkowania się Bożemu objawieniu (w tym boskim ustaleniom i nakazom) w obliczu własnych skłonności, jak też kuszenia ze strony dżinów (tj. złych duchów, którym przewodzi Iblis - Szatan) mających 
na celu wystawienie człowieka na próbę, co z kolei Bóg aprobuje (Koran XXXVIII: 82-88). Człowiek bowiem powinien uwierzyć w Boże miłosierdzie, sprawiedliwość oraz zamysł Stwórcy. Możemy się o tym przekonać otwierając kolejne sury Koranu, które rozpoczynają się od słów „W imię Boga Miłosiernego, Litościwego!”, bądź też „Niech będzie błogosławiony najlepszy z Twórców” (Koran XXIII: 14).

Przywołane wersety nabierają szczególnego znaczenia, w kontekście podjętej w tekście dyskusji nad wartościowaniem życia ludzkiego. Wskazują bowiem, na jednoczący związek życia z przynależną mu wartością, w kontekście bożej obecności i aktywności. Innymi słowy, w tradycji koranicznej życie ludzkie (al-Hayy) ma wartość, gdyż zostało stworzone przez Boga, który je uformował oraz uświęcił, stanowi ono wynik jego aktywności, jest najbardziej elementarną i szczególną oznaką boskiej obecności, najdoskonalszym z bożych fenomenów, gdyż wyłącznie takie może być życie powołane do istnienia przez najlepszego (z możliwych do pomyślenia) Stwórcę Świata. Obdarzony, takim też życiem człowiek powinien swoje życie doceniać i szanować, jako że niczego lepszego ponad swoje życie, które Miłosierny Bóg mu w darze ofiarował nie otrzyma. Co więcej, jeżeli życie człowieka zostało uformowane podług boskiego planu, istotną część jego stanowiąc, to takie życie na mocy boskiego planu samo w sobie ma wartość, którą utracić może w momencie, czy to negacji boskiego konceptu, czy też odstąpienia od wskazań Bożych. Stąd też nawoływanie myślicieli islamskich do zawierzenia Bogu. Azim Nanji podkreśla przykładowo, że [...] słowo islam oznacza pierwotne objawienie, wymagajace podporządkowania sie [i zawierzenia Allachowi] w celu osiagnięcia równowagi, a muzułmanin to ktoś, kto szuka $w$ działaniu osiagnięcia owej równowagi $w \dot{z} y c i u$ prywatnym i społecznym (Nanji 1998: 143). Stąd też filozofia islamska i odwołująca się do niej (bio)etyka podkreślać będą naglącą potrzebę podporządkowania się bożym przykazaniom, jak też zawierzenia Allachowi, zamiast popadania, z jednej strony w partykularny egocentryzm, z drugiej natomiast ulegania ulotnym i często destrukcyjnym dla nas skłonnościom, dla których fundament stanowić może nieokiełznana 
aktywność poznawcza. W odpowiedzi na wskazane wyżej trudności islamska myśl filozoficzno-antropologiczna, czy też etyczno-społeczna waloryzować będzie, z jednej strony wartość życia człowieka wspólnotowego przed jednostkowym (prywatnym), $z$ drugiej natomiast ganić będzie działania sprzeczne $\mathrm{z}$ bożym zamysłem, $\mathrm{m}$. in. w obszarze wzmożonej aktywności poznawczej człowieka na polu naukowo-technologicznym.

W pierwszym przypadku myśliciele islamscy, w tym filozofowie i (bio)etycy podkreślać będą zasadnicze znaczenie wspólnoty ludzkiej dla wartościowania życia ludzkiego, w drugim natomiast wskazywać będą niepokoje towarzyszące rozwojowi naukowo-technologicznemu. Zauważyć jednak trzeba, że zarysowane wyżej płaszczyzny przecinają się, czy też pokrywają finalnie w dyskusji nad wartościowaniem życia ludzkiego, choć tę, jak postaram się wykazać poniżej można poprowadzić rozdzielnie, tj. pod kątem „socjologiczno-antropologicznym”, jak również „(bio)etyczno-aksjologicznym”.

Jako punkt wyjścia „socjologiczno-antropologicznej” refleksji nad wartościowaniem życia ludzkiego wskazuje się w islamie szyicko-sunnickim znaczenie wspólnotowej wartości życia ludzkiego $\mathrm{w}$ ramach ummy, tj. społeczności wiernych, dla której jednostka jest elementem nieodrodnym całości, stanowi ogniwo organizmu społecznego, a co się z tym wiąże interesy jednostkowe powinny być podporządkowane interesowi społecznemu. Jedność wiernych oraz łączące ich braterskie więzi, zarówno Koran, jak i sunna uznają za stojące niezwykle wysoko w społecznej hierarchii aksjologicznej, co widoczne jest już w sposobie, w jaki Allach zwraca się do zgromadzenia muzułmanów, nigdy zaś do poszczególnego (pojedynczego) wiernego.

Dla przykładu:

„O ludzie!

Oto stworzyliśmy was z mężczyzny i kobiety

i uczyniliśmy was ludami i plemionami, abyście się wzajemnie znali.

Zaprawdę, najbardziej szlachetny spośród was, 
w obliczu Boga,

to najbardziej bogobojny spośród was!”

(Koran XLIX: 13)

Powyższy werset wskazuje na jeszcze jedną istotną wartość wspólnotową, a mianowicie na taqwa, jako koraniczny ideał etyczno-moralny, aksjo-teologiczny oraz prawny, którym dla islamu jest bogobojność, stanowiąca [...] fundament moralności, leżący u podstaw działania ludzkiego, $z$ drugiej zaś [taqwa to zaszczepiona nam przez Boga jedna z zasadniczych praktyk do urzeczywistnienia, tj.] sumienie, które sprawia, $\dot{z}$ istoty ludzkie staja się świadome swych obowiązków względem Boga i społeczeństwa (Nanji 1998: 143).

Co więcej, jednostka realizująca w życiu osobistym wspomniane obowiązki (względem Boga i społeczeństwa) jest w pełni odpowiedzialna za ich przebieg nie tylko przed Bogiem, ale także przed umma, która zawarła przymierze z Allachem. Rola wspólnoty uwidoczniona zostaje również, w konstrukcji piątego „przykazania” islamskiego, tj. had $\dot{z} d \dot{z}$ (pielgrzymki do Mekki, która służy wzmocnieniu więzi łączących wspólnotę, ukazaniu jej siły, jak również przypomnieniu wiernym, jakie wartości są i powinny być realizowane przez wspólnotę, kto je opiniuje i weryfikuje, pozostając ich konstytutywnym nośnikiem). Wspomniany w poniższym tekście Al-Ghazali, przywołuje hadis, w którym Prorok Mahomet ganiąc podważanie wartości życia wspólnoty oraz należnego jej prestiżu, nawołuje do jej obrony, w słowach $[K]$ tokolwiek chciałby poróżnić zgodne zdanie [...] ummy, użyjcie miecza, kimkolwiek on byt (Muslim) (Al-Ghazali 1994: 152; Cyrzan 1997: 160).

W nakreślonej powyżej perspektywie można zatem mówić o wymiarze życia ludzkiego, tak jednostkowego, jak i społecznego, a tym samym o wartości życia ludzkiego realizowanej na wspomnianych dwóch płaszczyznach, przy czym zaznaczyć trzeba, że wymiar wspólnotowy życia ludzkiego ma charakter priorytetowy, gdyż stoi wyżej w hierarchii aksjologicznej, niźli jednostkowy. Co więcej, to ostatecznie w gestii wspólnoty pozostaje ustalanie i petryfikacja szczególnie pożądanych społecznie norm i wartości, bez których prawidłowe funkcjonowanie 
wspólnoty, czy społeczeństwa mogłoby zostać zaburzone. Rzeczone wartości wspólnotowe będą, z kolei brane pod uwagę przez islamskich (bio)etyków próbujących rozwikłać określoną sytuację dylematyczną w sposób zgodny z interesem społecznym, jak ma to przykładowo miejsce $\mathrm{w}$ przypadku oceny problematu wspomaganej reprodukcji, aborcji, czy eutanazji, pod kątem takich wspólnotowo (społecznie) ważnych wartości, jak m.in. rodzina, macierzyństwo, odpowiedzialność, zaufanie, itd.

Chcąc przybliżyć zgodne z Koranem znaczenie ummy dla podjętego w tekście zagadnienia wartościowania życia ludzkiego, uczeni islamscy podkreślają, że zakłada ona równowartość wszystkich ludzi w obliczu Allacha, bez podziałów na rasę, czy płeć, a jedynym dozwolonym wyróżnikiem jest wyodrębnienie tych, którzy wierzą w Boga, od osób niewierzących, chociaż ich wartość życia równa jest wierzącym, gdyż nadana zostaje przez Stwórcę wszelkiego życia - Allacha. Nadmienić przy tym należy, iż przyjęty w tradycji islamsko-muzułmańskiej model wspólnotowy zakładając jedność ludzi - wiernych w Bogu (umma), kładzie nacisk wyrażony wprost [...] przez Koran na etykę wyrównywania niesprawiedliwości $w$ życiu ekonomicznym i społecznym. [Pismo nakłania wobec tego] jednostki do przeznaczenia swych bogactw czy majątku na: 1) rodzine i krewnych; 2) sieroty; 3) biednych; 4) bezdomnych podróżnych; 5) potrzebujących; 6) oswobodzenie zniewolonych. Akty takie określają odpowiedzialność muzutmanina za rozwijanie sumienia społecznego i dzielenie się środkami osobistymi i komunalnymi z mniej uprzywilejowanymi (Nanji 1998: 143, Koran XVII: 26; IV: 2). Powyżej przedstawione wskazania koraniczne są niezwykle istotne, w perspektywie wartościowania życia ludzkiego. Po pierwsze bowiem wskazują, że u podstaw prawidłowego funkcjonowania wspólnoty leżeć winna etyka wyrównywania niesprawiedliwości (społeczno-ekonomicznych) wsparta na czwartym „przykazaniu” (nakazie, lub fundamencie) islamu, którym jest zakat, tj. ciążący na jednostce obowiązek oddawania, dzielenia się z potrzebującymi, czy pomocy, traktowany jako wielka cnota prowadząca do oczyszczenia. Co więcej, zakat w rozumieniu sze- 
rokim (na co uwagę zwraca koraniczna bioetyka islamska) to wspomożenie potrzebujących, cierpiących, chorych, dysfunkcyjnych, to m.in. pomoc medyczna oraz opieka lekarska. Po wtóre, Koran nadaje priorytet poszanowaniu życia drugiego człowieka w jego odmienności religijnej, jak i kulturowej, nakazując kategorycznie, by w relacjach z drugim człowiekiem nie kierować się uprzedzeniami, wrogością, czy nienawiścią, gdyż wszyscy tworzymy ummę, o czym zostało napisane, m.in. w surze V („stół zastawiony”), tj.

„Dla każdego z was uczyniliśmy normę i drogę otwartą.

A gdyby Bóg zechciał,

to uczyniłby was jednym narodem,

lecz [dąży do tego] żeby was doświadczyć

w tym, co wam dał.

Starajcie się więc pilnie

Czynić dobre dzieła.

Do Boga powrócicie wszyscy razem.

On obwieści wam to, w czym się różniliście."

(Koran V: 48)

Pamiętać przy tym należy, iż omówiona wcześniej szaria (tj. skodyfikowane prawo islamu) w ramach wspomnianych powyżej kategorii oceniania wszelkich działań, nakazuje udzielanie zakat potrzebującym, z uwagi na szacunek należny wspólnocie (umma) i Bogu. Tymczasem odrzucenie zakat, stanowi wyraz niegodziwości, w wymiarze tak moralnym, jak też prawno-społecznym, czy wreszcie teologicznym, uderza bowiem w interes wspólnoty, jak też w Boga, który powołał ją do istnienia mocą swojej miłości i nakazał udzielanie zakat.

Spoiwem łączącym ummę, poczynając od jej komórki podstawowej, tj. rodziny, będzie w islamskiej myśli koranicznej miłość, życzliwość i szacunek. Koran mówi wprost, już w surze I, o miłości, która należna jest Allachowi, jednak nie tylko jego nakazuje miłować, lecz także rodziców, bliźnich i „to co nas dalej otacza”. Zwrócić należy jednak uwagę, na fakt, że Boga powinniśmy obdarzać czcią, rodziców zaś Koran nakazuje szanować. 
I postanowił twój Pan,

abyście nie czcili nikogo innego,

jak tylko Jego;

i dla rodziców - dobroć!

A jeśli jedno $z$ nich lub oboje

osiągną przy tobie starość,

to nie mów im: „precz !"

i nie popychaj ich,

lecz mów do nich słowami pełnymi szacunku!

(Koran XVII: 23)

Shakir Kitab dodaje do powyższego, że uquq (tj. nieposłuszeństwo względem rodziców) to grzech ciężki mający znamiona przestępstwa, którym w islamie jest kabira (sytuującą się na drugiej pozycji, w hierarchii aksjologiczno-teologicznej zaraz po wielobóstwie). Na rzeczony stan rzeczy wpływ ma, jak zauważa prof. Seyyed Muhammad Husayn Tabatabai rozumienie społeczeństwa, jako wspólnoty rodziców i dzieci, w której to rodzice stanowią bazę, korzenie, czy trzon społeczeństwa, które można zdestabilizować, bądź zniszczyć poprzez niewłaściwe, $\mathrm{w}$ tym niesprawiedliwe oraz krzywdzące postępowanie względem rodziców. Szkodząc wobec powyższego rodzicom, osłabiamy wsparte na ich obecności społeczeństwo, co w islamie jest niedopuszczalne (por. Al-Ghazali 1994: 152). Dodać można, że w perspektywie teologicznej krzywdziciel nigdy nie dostąpi zbawienia i nie zazna szczęścia danego tylko sprawiedliwym, na co jednoznacznie wskazuje myśl koraniczna (Kitab 2000: 61).

Dla filozofii i etyki islamskiej rodzina stanowi podstawową komórkę społeczną, uznawaną za świętą, umacnianą poprzez miłość, tolerancję i poszanowanie, w której to krystalizują się normy i wartości społecznie ważne, jak odpowiedzialność, zaufanie, troska i wiele innych. Z kolei koraniczna (bio)etyka islamska przywołuje (aksjologiczno)-teologiczny model rodziny, jako model wzorcowy, podczas analizy takich kwestii, jak rola macierzyństwa a w jej ramach dopuszczalność aborcji, czy choćby wspomagana reprodukcja versus prokreacja naturalna. 
Islam nakazuje ponadto miłość i szacunek wobec wszystkich bliźnich wiernych w Bogu, gdyż wszyscy ludzie są dla siebie braćmi i siostrami (por. Kitab 2000: 62-63), co podkreślono w Koranie w następujących słowach:

Jeśli dwie partie spośród wiernych

zwalczają się,

to ustanówcie między nimi pokój.

A jeśli jedna $\mathrm{z}$ nich

będzie nadal występować przeciw drugiej,

to zwalczajcie tę, która się buntuje,

aż zwróci się ku rozkazowi Boga.

A jeśli się podda,

to ustanówcie między nimi pokój

według sprawiedliwości

i postępujcie bezstronnie!

Zaprawdę, Bóg miłuje ludzi,

którzy postępują według słuszności.

Wierni są przecież braćmi!

Ustanawiajcie więc pokój

między waszymi dwoma braćmi.

(Koran XLIX: 9-11)

Tak wreszcie przechodzimy do ostatniego, z kluczowych z perspektywy filozofii i bioetyki koranicznej pytania, o możliwość, dopuszczalność, jak też ocenę zabicia drugiego człowieka.

W wymiarze moralno-prawnym Koran potępia zabijanie drugiego człowieka, podkreślając, iż nakaz poszanowania wartości życia drugiego człowieka musi mieć charakter absolutny. W zarysowanej perspektywie powinien stać się zatem paradygmatem moralnego postępowania, czy też imperatywem kategorycznym, który swoim zasięgiem obejmowałby wszystkich ludzi, albowiem, jak podkreśla Koran, zabicie choć jednego człowieka równa się popełnieniu kabira (grzechu najcięższego), tj. zabiciu wszystkich ludzi. Wspomniany już w tekście Shakir Kitab dodaje również, że [I]slam traktuje życie ludzkie jako wartość święta 
i zabijanie choć jednego człowieka równa się zabijaniu wszystkich ludzi. [Jako że] rodzaj ludzi jest jeden, przestępstwo wobec jednego człowieka liczy się jako przestępstwo przeciw całemu rodzajowi (Kitab 2000: 67).

W Koranie zostało, z kolei napisane:

„Ten, kto zabił człowieka,

który nie popełnił zabójstwa

i nie szerzył zgorszenia na ziemi,

czyni tak, jakby zabił wszystkich ludzi.

A ten, kto przywraca do życia człowieka,

czyni tak,

jakby przywracał do życia wszystkich ludzi.”

(Koran V: 32)

Szczególnie silnie w tradycji islamskiej piętnuje się zabicie osoby wierzącej (niezależnie od jej wyznania), co odnajdujemy w przekazie proroka Mahometa, który zauważał, że zabójstwo (morderstwo) to grzech bardzo ciężki, od którego większym może być tylko wielobóstwo. O ile jednak islam dopuszcza formę odpłaty (diyah) za nieumyślne zabicie człowieka, o tyle nie dopuszcza takiej możliwości w przypadku zabójstwa celowego (umyślnego) osoby wierzącej.

W Koranie napisane przeto zostało:

„A kto zabije wierzącego naumyślnie, to zapłatą dla niego będzie Gehenna, gdzie będzie przebywał wiecznie.

Bóg rozgniewał się na niego

i przeklął go,

i przygotował dla niego karę ogromną."

(Koran IV: 93)

W nakreślonej powyżej perspektywie życie ludzkie jawi się zatem, jako wartość absolutna, należy je bezwzględnie chronić i szanować, co Koran wyraża między innymi w surze XVII: 
I nie zabijajcie waszych dzieci

z obawy przed niedostatkiem,

My im damy zaopatrzenie,

podobnie jak wam.

Zaiste zabijanie ich

jest wielkim grzechem!

[...]

I nie pozbawiajcie nikogo życia

które Bóg uczynił świętym

chyba że zgodnie z prawem!

(Koran XVII: 31, 33)

W obliczu tego, co zostało powiedziane dotychczas, zauważyć należy, że filozofowie oraz (bio)etycy islamscy wartościując ludzkie życie (al-Hayy), czynią to w oparciu o świadectwo Koranu i sunny. Te z kolei, jednoznacznie wskazują, że życie ludzkie stworzone zostało przez Allacha, na jego obraz i podobieństwo, tudzież wzór jego idei. Bóg, w akcie kreacji obdarza nas rozumnością (al- 'agl), jak również wolną wolą, w akcie zaś animacji nieśmiertelną duszą (nafs), przez które to człowiek staje się następcą Boga (chalifa) na ziemi (Koran II: 30), tym którego Stwórca chciał dla niego samego, którego honoruje (Koran XVII: 70), tym wreszcie, którego Bóg ponownie powoła przed swoje oblicze i oceni, jako że tylko Allach jest dawcą i biorcą wszelkiego istnienia, tym który [...] wyprowadza żywe [lub żyjące] $z$ martwego $i$ [...] martwe $z \dot{z}$ ywego [lub żyjącego] (Koran II: 258, III: 27, III: 156, VI: 95, X: 31, XXII: 6, LIII: 44, LVII: 2), ganiąc niemoralność i niesprawiedliwość (Koran XXXIII: 72, LXXII: 4-5, XCI: 8) nawołując człowieka do roztropności (rozwagi) i odpowiedzialności (Koran XLV: 13) za życie własne, wspólnoty (ummy), w której żyjemy oraz świata otrzymanego w zaufaniu przez Boga (do rozsądnej dyspozycji). Obdarzony zaufaniem Allacha człowiek, zyskuje szczególny status osobowy, przynależy mu wrodzona godność ${ }^{11}$, życiu zaś jego przydana zostaje w darze od

11 W islamie przyjmuje się, że godność człowieka ma charakter duchowo-cielesny, ponieważ „rozciąga się” również na nasze ciało. W związku z powyższym, nie wolno ciału szkodzić, czy też lekceważyć jego potrzeb. Co więcej, człowiek nie traci 
Stwórcy (wsobna) wartość absolutna, którą utracić może jedynie poprzez czyny niegodne.

Nakreślone wyżej stanowisko koranicznej etyki i odwołującej się do niej bioetyki islamskej (w tym również aksjomedycyny, etyki medycznej, czy też nawiązującego do nich bioprawa) w kwestii wartościowania życia ludzkiego, stało się jednocześnie punktem odniesienia dla podjętej przez myślicieli islamskich szerszej dyskusji szczegółowych kwestii bioetycznych, z obszaru początków życia ludzkiego, jego trwania, jak też kresu ludzkiego życia.

\section{Bibliografia}

Abdur-Rashid K., Furber S.W., Abdul-Basser T., 2013, Lifting the veil: a typological survey of the methodological features of Islamic ethical reasoning on biomedical issues, Theor. Med. Bioeth., Vol. 34(2), s. 81-93.

Al-Ghazali M., 1994, Zasady moralności islamu, Stowarzyszenie Studentów Muzułmańskich w Polsce, Białystok.

Atighetchi D., 2000, Islamic tradition and medically assisted reproduction, Mol Cell Endocrinol., Vol. 169(1-2), s. 137-141.

Atighetchi D., 1994, The position of Islamic tradition on contraception, Med Law, Vol. 13(7-8), s. 717-725.

Biesaga T., 2007, Spór o moralny status człowieka $w$ okresie prenatalnym, Medycyna Praktyczna, Ginekologia i Położnictwo, Vol. 1, s. 9-13.

Cyrzan H., 1997, Człowiek w tak zwanych religiach ksiegi, w: Cyrzan H. (red.), „Życie jako wartość w kulturach świata”, UG, Gdańsk, s. 150-165.

Daar A.S., Al-Khitamy A.B, 2001, Bioethics for Clinicians: 21. Islamic Bioethics, CMAJ, Vol. 164(1), s. 60-63;

godności, w wyniku śmierci, gdyż ta wykracza poza kres naszego życia ziemskiego (Hurr ' Amili 1392: Ch. 25). Dla rozważań poświęconych wartościowaniu życia ludzkiego oznacza to, że każdy człowiek, w tym nieanimowany (wczesny) embrion, jak i osoba pozbawiona świadomości (np. przebywająca w stanie wegetatywnym) posiada przydaną przez Allacha stałą godność. 
El-Abbadi A.S., 1990, The Rights of the Embryo: Muslim response, in: The Rights and Education of Children in Islam and Christianity, Acts of a Muslim-Christian Colloquium, Vatican Press, Rome, s. 23-32.

Gatrad A.R., Sheikh A., 2001, Medical ethics and Islam: principles and practice, Arch Dis Child, Vol. 84, s. 72-75;

Hallaq W., 2009, An introduction to Islamic law, Cambridge University Press, Cambridge.

Hurr ' Amili M., 1392, Diyat al-a 'da, in: Wasaa'il al-Shi'ah. Qum: Ismaaa'iliyan, Vol. 19, Ch. 25.

Brockopp J.E. (eds.), 2003, Islamic ethics of life: abortion, war, and euthanasia, University of South Carolina Press, South Carolina.

Jaroszewski T.M., 1970, Osobowość $i$ wspólnota, Książka i Wiedza, Warszawa.

Katechizm Kościoła Katolickiego, Pallottinum, Poznań 1994.

Kitab S., 2000, Dekalog żydowsko-chrześcijański w oczach islamu, wyd. Adam Marszałek, Toruń.

Koran, przeł. Bielawski J., wyd. Państwowy Instytut Wydawniczy, Warszawa 1986.

Larijani B., Zahedi F., 2004, Islamic Perspective on Human Cloning and Stem Cell Research, Transplant Proc., Vol. 36(10), s. 3188-3189.

Majlesi M.B., 1983, Bihaar al-Anwar, Beirut: Al-Wafaa, Vol. 59.

Nanji A., 1998, Etyka islamska, w: Singer P. (red.), „Przewodnik po etyce”, Książka i Wiedza, Warszawa.

Nasr S.H., 1988, Idee i wartości islamu, PWN, Warszawa.

Padela A.I., 2007, Islamic Medical Ethics: A Primer, Bioethics, Vol. 21(3), s. $169-178$.

Piwiński R., 1983, Mity i legendy w krainie Proroka, wyd. Artystyczne i Filmowe, Warszawa.

Shomali M.A., 2008, Islamic bioethics: a general scheme, J Med Ethics Hist Med, Vol. 1, s. 1-8.

Singer P., 1998, Przewodnik po etyce, wyd. Książka i Wiedza, Warszawa. Szawarski Z., 1985, Wartość życia, Etyka, Vol. 21, s. 41-69.

Wilowski W., 2000, Zagadnienie życia i śmierci w wybranych pogladach filozoficznych i religijnych, UAM, Poznań. 